\title{
ANTI-HEPATITIS A VIRUS FREQUENCY IN ADOLESCENTS AT AN OUTPATIENT CLINIC IN SÃO PAULO, BRAZIL
}

\author{
Maria Isabel Saraiva DINELLI(1), Mauro FISBERG(2) \& Maria Isabel de MORAES-PINTO(1)
}

\begin{abstract}
SUMMARY
The prevalence of hepatitis A virus (HAV) antibodies was assessed in adolescents (age ranging from 10.4 to 19.9 years) at an Adolescent Outpatient Clinic in São Paulo, Brazil. Anti-HAV was detected in 137 (54.2\%) out of 253 individuals. When separated into two age groups, anti-HAV frequency was higher in the 15 to 19 year-old group (64\%) in comparison to the 10 to 14 year-old group (46\%) (Chi-square test: $\mathrm{p}=0.004)$. These results suggest that adolescents in São Paulo are at risk of hepatitis A infection and are probably contracting HAV infection during this age period.
\end{abstract}

KEYWORDS: Hepatitis A; Adolescents; Seroprevalence; Brazil.

\section{INTRODUCTION}

The epidemiological pattern of hepatitis A virus (HAV) infection has been changing in Latin America in the last few years. Some countries shifted from high to intermediate rates of antibody seroprevalence ${ }^{12,13}$. Intermediate endemicity was also observed in the Northeastern, Southern and Southeastern regions of Brazil ${ }^{4}$. In São Paulo State there was an important decrease in antibody prevalence rate in the last two decades ${ }^{7,9}$, probably related to an improvement in socioeconomic conditions.

It is noteworthy that many Brazilian studies have shown an inverse relation between seroprevalence of HAV infection and socioeconomic and sanitary conditions $1,4,6,9,10,11,14$.

Periodic and updated seroprevalence studies are important tools to evaluate the susceptibility of a population to HAV infection and project Public Health policies.

\section{MATERIAL AND METHODS}

From May to the beginning October 2001, 253 adolescents (age ranging from 10.4 to 19.9 years, $63 \%$ male and $37 \%$ female) were assessed at the Adolescent Outpatient Clinic of the Federal University of São Paulo in São Paulo, Brazil. Around 240 adolescents attend the Clinic every month, and individuals come mainly from middle/low socioeconomic class.

Adolescents were invited to participate in this study and a questionnaire and blood sample were collected on the same day. Most new patients were included in the study and one in each four individuals already followed up at the Clinic was recruited. Information regarding home water supply and public sewerage service was obtained.

Qualitative determination of antibodies to hepatitis A virus (antiHAV) was performed using a competitive ELISA commercial kit (DiaSorin, Italy). The study was submitted to the Ethics Committee and written informed consent was obtained before enrolment.

\section{RESULTS}

The prevalence of anti-HAV in adolescents was 54.2\% (137/253). When separated into two age groups, those from the 10 to 14 year-old group showed lower hepatitis A seroprevalence than those from the 15 to 19 year-old group (46\% versus $65 \%$, respectively; Chi-square test, $\mathrm{p}=0.004)$.

Four individuals had previously received vaccine against hepatitis A and had anti-HAV antibodies. Eleven adolescents reported hepatitis A infection in the past and anti-HAV was detected in ten of them $(90.9 \%)$.

Anti-HAV seropositivity was found in 132/246 (53.7\%) of adolescents living in houses with public water supply, and in 5/7 $(71.4 \%)$ without it. (Fisher's exact test, $\mathrm{p}=0.46)$. Antibodies against HAV were present in 109/210 (51.9\%) individuals living in houses with public sewerage service and in $28 / 43(65.1 \%)$ of those without it (Chi-square test, $\mathrm{p}=0.11$ ). 


\section{DISCUSSION}

In this study, $46.8 \%$ adolescents were susceptible to hepatitis A virus infection. This is especially worrying because the disease is frequently symptomatic in adolescents and adults, while hepatitis A infection in children is usually asymptomatic or has nonspecific manifestations $\mathrm{s}^{2,3}$.

Lower anti-HAV seroprevalence rates were obtained in a previous study performed in São Paulo city including individuals from all socioeconomic levels: $36 \%$ and $56 \%$ among 10 to 14 year-old adolescents and 15 to 19 year-old ones, respectively ${ }^{7}$. This difference may be due to the fact that the population in our study belonged to the middle/low socioeconomic group.

Anti-HAV seropositivity was higher in individuals living in houses without public water supply or sewerage service. However, that difference was not statistically significant probably because of the sample size.

As already shown in previous studies, our data points to a decrease in HAV seroprevalence in Brazil ${ }^{4,7}$. However, the higher percentage of HAV seropositive individuals from 15 to 19 years in comparison to those from 10 to 14 years suggests that many individuals might be infected by hepatitis A virus during adolescence.

Besides improvement in education and sanitary conditions, immunization against hepatitis A could be a strategy to prevent infection. In regions of intermediate endemicity like the city of São Paulo, large-scale vaccination in childhood may be considered. Interestingly, a vaccination program with preadolescents in Catalonia, Spain, reduced the incidence of hepatitis A infection in all age groups below 60 years of age ${ }^{5,8}$.

\section{RESUMO}

\section{Soroprevalência de hepatite $\mathrm{A}$ em adolescentes de ambulatório em São Paulo, Brasil}

A prevalência de anticorpos contra o vírus da hepatite A foi avaliada em adolescentes de 10,4 a 19,9 anos atendidos no Ambulatório de Adolescentes da Universidade Federal de São Paulo. Entre 253 indivíduos analisados, a prevalência de anticorpos foi de 54,2\%. Quando os adolescentes foram separados em duas faixas etárias, a prevalência foi maior no grupo de 15 a 19 anos (64\%) em comparação com os de 10 a 14 anos (46\%) (Qui-quadrado: $p=0,004)$. Estes resultados sugerem que muitos adolescentes de São Paulo estão sob risco de infecção pelo vírus da hepatite A e alguns deles estão provavelmente se infectando durante a adolescência.

\section{ACKNOWLEDGEMENT}

We thank "Fundo de Auxílio ao Docente e ao Aluno" (FADA) of the Federal University of São Paulo, for financial support.

\section{REFERENCES}

1. ALMEIDA, L.M.; WERNECK, G.L.; CAIRNCROSS, S. et al. - The epidemiology of hepatitis A in Rio de Janeiro: environmental and domestic risk factors. Epidem. Infect., 127: 327-333, 2001.

2. AMERICAN ACADEMY OF PEDIATRICS - Hepatitis A. In: PICKERING, L.K., ed. Red book. Report of the Committee on infectious diseases. 26 ed. Elk Grove Village, American Academy of Pediatrics, 2003. p. 309-310.

3. ARMSTRONG, G.L. \& BELL, B.P. - Hepatitis A virus infection in the United States: model-based estimates and implications for childhood immunization. Pediatrics, 109: $839-845,2002$

4. CLEMENS, S.A.C.; FONSECA, J.C.; AZEVEDO, T. et al. - Soroprevalência para hepatite A e B em quatro centros no Brazil. Rev. Soc. bras. Med. trop., 33: 1-10, 2000.

5. DOMINGUEZ, A.; SALLERAS, L.; CARMONA, G. \& BATALLA, J. - Effectiveness of a mass hepatitis A vaccination program in preadolescents. Vaccine, 21: 698-701, 2003.

6. FERREIRA, C.T.; SILVA, G.L.; BARROS, F.C. \& PEREIRA-LIMA, J. Soroepidemiologia da hepatite A em dois grupos populacionais economicamente distintos de Porto Alegre. GED, 5: 85-90, 1996.

7. FOCACCIA, R.; CONCEIÇÃO, O.J.G.; SETTE Jr., H. et al. - Estimated prevalence of viral hepatitis in the general population of the municipality of São Paulo, measured by a serologic survey of a stratified randomized and residence-based population. Braz. J. infect. Dis., 2: 269-284, 1998.

8. LOPALCO, P.L.; SARELLAS, L.; BARBUTI, S. et al. - Hepatitis A and B in children and adolescents: what can we learn from Puglia (Italy) and Catalonia (Spain). Vaccine, 19: 470-474, 2001.

9. PANNUTI, C.S.; MENDONÇA, J.S.; CARVALHO, M.J.M.; OSELKA, G.W. \& AMATO NETO, V. - Hepatitis A antibodies in two socioeconomically distinct populations of São Paulo, Brazil. Rev. Inst. Med. trop. S. Paulo, 27: 162-164, 1985.

10. PINHO, J.R.R.; SUMITA, L.M.; MOREIRA, R.C. et al. - Duality of patterns in hepatitis A epidemiology: a study involving two socioeconomically distinct populations in Campinas, São Paulo State, Brazil. Rev. Inst. Med. trop. S. Paulo, 40: 105-106, 1998.

11. SABACK, F.L.; PALMER, T.E.; SABINO, R.R. et al. - Infection with hepatitis A and TT viruses and socioeconomic status in Rio de Janeiro, Brazil. Scand. J. infect. Dis., 33: $121-125,2001$.

12. TANAKA, J. - Hepatitis A shifting epidemiology in Latin America. Vaccine, 18: S57S60, 2000.

13. TAPIA-CONYER, R.; SANTOS, J.I.; CAVALCANTI, A.M. et al. - Hepatitis A in Latin America: a changing epidemiologic pattern. Amer. J. trop. Med. Hyg., 61: 825$829,1999$.

14. VITRAL, C.L.; YOSHIDA, C.F.T.; LEMOS, E.R.S.; TEIXEIRA, C.S. \& GASPAR, A.M.C. - Age-specific prevalence of antibodies to hepatitis A in children and adolescents from Rio de Janeiro, Brazil, 1978 and 1995. Relationship of prevalence to environmental factors. Mem. Inst. Oswaldo Cruz, 93: 1-5, 1998.

Received: 17 March 2005

Accepted: 29 September 2005 